\title{
Measuring income inequality: comparative datasets and methodological deficiencies. An overview of income inequality in Romania during postsocialism
}

\author{
Ionuț-Marian Anghel ${ }^{1 *}$ \\ ${ }^{1}$ Romanian Academy, Research Institute for Quality of Life, School for Advanced Studies, 13 Calea 13 Septembrie, \\ 050711 - Bucharest, Romania.
}

KEYWORDS

Income inequality

Comparative datasets

Methodological pitfalls

Neoliberalism

Postsocialism

Romania

\section{A BSTRACT}

The article delineates the main methodological deficiencies and datasets available for comparing income inequality at the European and world level. The article is divided in two parts. In the first part of the article, I present the main datasets and methodological deficiencies when trying to compare income inequality in the world. Although efforts have been made in the last decades to generate comparative databases, the qualities of some indicators are rather doubtful and also there is no common ground on conceptualizing inequality indicators and measuring them, some of which are income-based, while others are household expenditure-based. Then, I present two classical studies on studying income inequality after the Washington consensus. In the second part of the article I sketch an overview of rising income inequality in Romania after 1989 by presenting some income inequality indicators and comparing them with other former CEE countries. However, I will pinpoint that Romania's case is rather exceptional in the EU and, when comparing standard income inequality indicators, further explication needs to be delivered. I conclude that while income inequality is the result of macro-structural changes that occurred during the transition to market capitalism, political decisions are not to be played-down.

* Contact address: ionut.anghel@iccv.ro (I.M. Anghel). 


\section{Introduction}

Income inequality growth in Romania is the result of macro-structural changes which occurred during the postsocialist transition to market capitalism, although, as I will show during this article, the transition itself cannot be the main cause for income inequality growth. A quarter of a century after the fall of the socialist regimes, income inequalities grew without exception in all former socialist countries, most of them being now members of the European Union (EU). If in 1989, the average Gini coefficient ${ }^{1}$ for the 12 countries that joined EU in the 2004 and 2007 waves was 22 (Bandelj and Mahutga 2010b), in 2014 it rose to 31. Romania is among the most unequal member states in the EU with a Gini coefficient of 37.4 in 2015, close to Bulgaria (37), but well above the EU average of 31. During the recent economic crisis, Romania experienced the 'largest drop' of the Gini coefficient in the EU (from 38.3 in 2007 to 33.5 in 2011) due to wage cuts in the public sector and shrinking profits from the real estate market (Domnișoru 2014). Once wages were restored and the economy returned to economic growth, the Gini coefficient raised again to 37.4 in 2015, only before Lithuania.

The present article aims to schematically discuss the methodological deficiencies for measuring income inequality and also causes of income inequality in Romania, although comparisons with other countries from EU will also be used. I will present the main sources of data used in this study, the methodologies for measuring income inequality (and also a critical engagement with this methodologies), as well as two classical studies measuring the latter. I will engage with Thomas Piketty's seminal work on the long-term tendency of capitalist systems to produce income inequality to understand how the latter can be favoured by political decisions and not only by market forces. Then, I will particularize this argument to CEE countries and critically interrogate Kuznets theory regarding rising income

\footnotetext{
${ }^{1}$ The Gini coefficient measures the extent to which the distribution of income within a country deviates from a perfectly equal distribution. A coefficient of 0 expresses perfect equality where everyone has the same income, while a coefficient of 100 expresses full inequality where only one person has all the income.
} 
inequality during time of structural changes, by arguing that his theory disregards the effects of specific public policies.

\section{Data sources in measuring income inequality}

In the last decades many efforts have been made to build comparative data sources at European/world level to measure income inequality. The largest project to build such a database belong to the World Bank consultants, Klaus Deininger and Lyn Squire. In the mid-1990s, they published a collection of 682 'high quality` Gini coefficients for 108 countries (out of the 220 countries), of which two thirds are taken from primary sources (official government statistics or data published by prestigious international agencies) (Deininger and Squire 1996, 572). The remaining 35\% are data obtained, according to the authors, from reliable secondary sources (research surveys). Even so, the number of high-quality Gini coefficients represents only one-quarter of the 2,621 cases for which the two economists have processed data. Thus, the coefficients are spread unevenly for the 220 countries compiled in the database and in many cases the information is scarce or absent. These are not the only shortcomings of the database compiled by the two researchers. James Galbraith $(2016,126)$ remarks that the indicators used by the two economists are based on gross incomes for some countries, while for others they use net incomes; in some cases the units of analysis are the households, while in other the individuals. Finally, for some countries, incomes are considered more relevant, while for other countries, they analyse consumption patterns. In consequence, researchers who use data compiled by Deininger and Squire cannot reach consistent and credible conclusions on what the data actually show.

Since the mid-1990s, the World Bank annually publishes Gini coefficients within the World Development Indicators Database, and although the institution has refined its methodology for data compilation, 
income and expenditure indicators are still used, and although they are not similar, are considered to be complementary ${ }^{2}$.

The Luxembourg Income Study Database (LIS) uses instead microdata at household level for more than 50 countries covering Europe, North America, Asia, Africa and Australia ${ }^{3}$. The micro-data sets are collected for variables such as labour income, capital income, taxes and contributions, social security, private transfers, demography and employment. The data collected in the LIS are considered among the most reliable micro-data available for comparative research. The major deficiency of the study, from the perspective of comparative study of global inequality, is that coverage is still low, with an emphasis, at least in recent years, on high-income countries. Romania was included in the project only in the fourth wave, with data collected in 1995 and 1997, thus quite old.

The World Institute for Development Economics Research (WIDER), a United Nations public think-thank, based in Helsinki, has also developed its own data-set, based on the data compiled by Klaus Deininger and Lyn Squire. The latest version of the World Income Inequality Database (WIID 3.4) contains data for 182 countries and 8,817 observations, of which 8,782 Gini coefficients, 5,690 observations on income distribution by quintile shares, and 5,006 observations on income distribution by decile shares ${ }^{4}$.

As with the data compiled by Deininger and Squire, no common concepts have been identified and comparability of coefficients remains low. The value of this database, as the one compiled by Deininger and Squire, is that they are vital depositors of past studies rather than updated comparative datasets [...] They are compilations done by hundreds of research teams around the world over the years` (Galbraith 2016, 126).

\footnotetext{
${ }^{2}$ Although for some countries (such as Romania) it is more relevant to use household expenditures rather than income indicators, the World Bank's Gini coefficients cannot be compared for all countries included precisely because of their compilation methodology

${ }^{3}$ The project started in 1967 and the last wave took place in 2014-2016. For details on the purpose, methodology and results of the project, see LIS website (http://www.lisdatacenter.org/our-data/lisdatabase/ and http://www.lisdatacenter.org/wp-content/uploads/our-lis-documentationharmonisation- guidelines.pdf).

${ }^{4}$ For more details on the WIID database, see WIID website (https://www.wider.unu.edu/project/wiidworld-income-inequality-database).
} 
Table 1. Coverage of the WIID database and the number of observations per country and time

\begin{tabular}{|l|l|}
\hline Countries included & $\mathbf{1 8 2}$ \\
\hline North America & 2 \\
\hline Latin America and Caribbean & 29 \\
\hline Europe & 44 \\
\hline North Africa and West Asia & 18 \\
\hline Sub-Saharan Africa & 48 \\
\hline Central Asia & 5 \\
\hline South Asia & 9 \\
\hline Eastern Asia & 6 \\
\hline South-East Asia & 10 \\
\hline Oceania & 11 \\
\hline Observations & $\mathbf{8 , 8 1 7}$ \\
\hline Gini coefficients & 8,782 \\
\hline Income distribution by quintile shares & 5,690 \\
\hline Income distribution by decile shares & 5,006 \\
\hline Time span & $\mathbf{8 , 8 1 7}$ \\
\hline Before 1960 & 306 \\
\hline $1960-69$ & 664 \\
\hline $1970-79$ & 757 \\
\hline $1980-89$ & 1,208 \\
\hline $1990-99$ & 2,215 \\
\hline $2000-09$ & 2,552 \\
\hline $2010-15$ & 1,115 \\
\hline
\end{tabular}

Source: WIID 3.4 (https://www.wider.unu.edu/news/new-data-income-inequality\%E2\%80\%93-wiid34-released, retrieved 11.07.2017) 
The European Union's Survey on Income and Living Conditions (EUSILC) has been in recent years the most used database for comparative studies at EU level, used mainly as a tool in order to achieve Europe 2020 headline indicators. Estimating income inequality in Romania using EUSILC is more difficult because of the high share of informal work, remittances from migration, the atypical occupational structure and the importance of own-consumption in reducing inequality. Thus, the income inequality growth after 1989 is mainly reflected by the differences between wages and incomes derived from work in subsistence agriculture (including unpaid family workers) and informal economy. Over $90 \%$ of the nearly 2 million individuals employed in agriculture are actually included in the category of unpaid family workers and subsistence agriculture, with low and fluctuating incomes. Incomes from own-consumption represents an important share for the bottom decile (43\%) and gradually decreases to $4 \%$ in the case of the top decile. Instead, the share of wages in the bottom decile is $8 \%$, while for the top decile it reaches $80 \%$ (see Figure 1 below).

Figure 1. Household income structure, by deciles (2014)

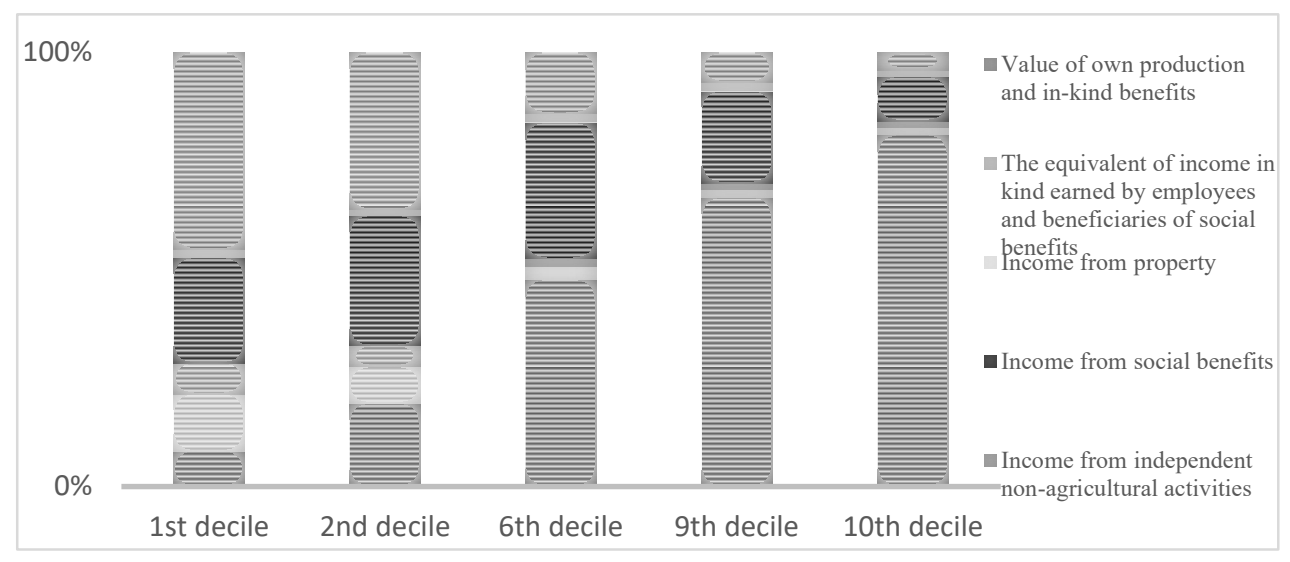

Source: Romania's Statistical Yearbook (2015)

According to EU-SILC, all households reported income from ownconsumption, while for other former socialist states the share ranges 
between 5 and 50\%. Moreover, income from household production represented $17 \%$ of household income on average, while for other countries the share does not exceed 2\% (Paats and Tiit 2010, 187). Even in these circumstances, which makes Romania an exceptional case in the EU, the incomes computed based on own-consumption decreases the value of the Gini coefficient by at least 4 percentage points (ICCV 2010, 34).

Describing the results of the EU-SILC survey, Eurostat acknowledges that the case of Romania is rather particular when assessing the income from own-consumption. The report admits that in Romania few questions have been used: from those who own land or are involved in production for own consumption, questions are asked about the field of agricultural activity and the extent of producing for their own household (Paats and Tiit 2010, 184). Also, for measuring the income obtained from own-consumption 'there is no information available about the method used (Paats and Tiit 2010, 184). As a consequence, the Gini coefficient reported by EU-SILC is higher than the one reported by the National Institute of Statistics (NIS) (which includes ownconsumption).

\section{Neoliberalism and income inequality: the winners take too much and the losers are to numerous ${ }^{-5}$}

In his seminal work ' Capital in the Twenty-First Century ', Thomas Piketty (2015) notes the long-term tendency of capitalist systems to produce income inequality and, above all, wealth inequality. According to Piketty, this is possible due to a fundamental law of capitalism, $r>g$, where $r$ represents the rate of return on capital, and $g$ represents the rate of economic growth. As long as $r$ is higher than $g$, there is a tendency to concentrate wealth and to income inequality growth. The French economist defines capital as the sum of both physical capital (equipment, buildings, real estate, land, etc.) and wealth, whether productive or not. A fundamental problem with the law described by Piketty is that he never explains where this rate of return on

${ }^{5}$ The subtitle is taken from (Hoffer, Laliberté, and Gross 2013, 3). 
capital originates, but simply states that it exists. For the French economist, the rate of return on capital would be around $5 \%$, while the growth rates of the economies (in high income countries) are below that share. Piketty demonstrates his hypothesis by analysing several empirical cases of highincome countries - the United Kingdom, the United States, France, Germany, Sweden, Japan, and Canada. The strength of his study is that the data used reflect a long period of time (from the 18th century for many countries) and that it focuses on detailing the richest 10,1 and $0.1 \%$ (and even $0.01 \%$ ) of the income distribution. The method used is the analysis of income and wealth statements.

According to Piketty's argument (2015), income and wealth inequalities would grow during periods of dis-embedded capitalism, that is, from the 18th century until 1910 (roughly before the outbreak of World War I) and after 1980, and would decrease in the period 1910-1970. Inequality in the latter period decreased due to the two world wars, when physical capital has been damaged and financial markets have suffered great losses or even collapsed. Moreover, social transformations in the post-war period and the development of the so-called welfare state have been materialized by workers' unionization and wage growths, the introduction of progressive income taxation and the nationalization of parts of the economy. Thus, the rate of return on capital after taxes would not have exceeded the rate of economic growth, meaning that $r<g$, and as a result, wealth and income inequality decreased. After 1970, this trend seems again to be reversed.

Due to space constraints, I will present an overview of trends in income and wealth accumulation in the case of the top decile and centile after 1980. I chose this year because it is a turning point in the political economy of global neoliberalism. It was in the early 1980s, when, according to David Harvey, the 'neo-liberal revolution' (Harvey 2007) took off, embodied in policies of deregulation of the economy, liberalization and privatization, and policy measures subsequently framed under the umbrella of the 'Washington Consensus' The data used are those from the project 
coordinated, among others, by Thomas Piketty - World Wealth and Income Database6.

Figure 2. The share in national income of the top decile (\%)

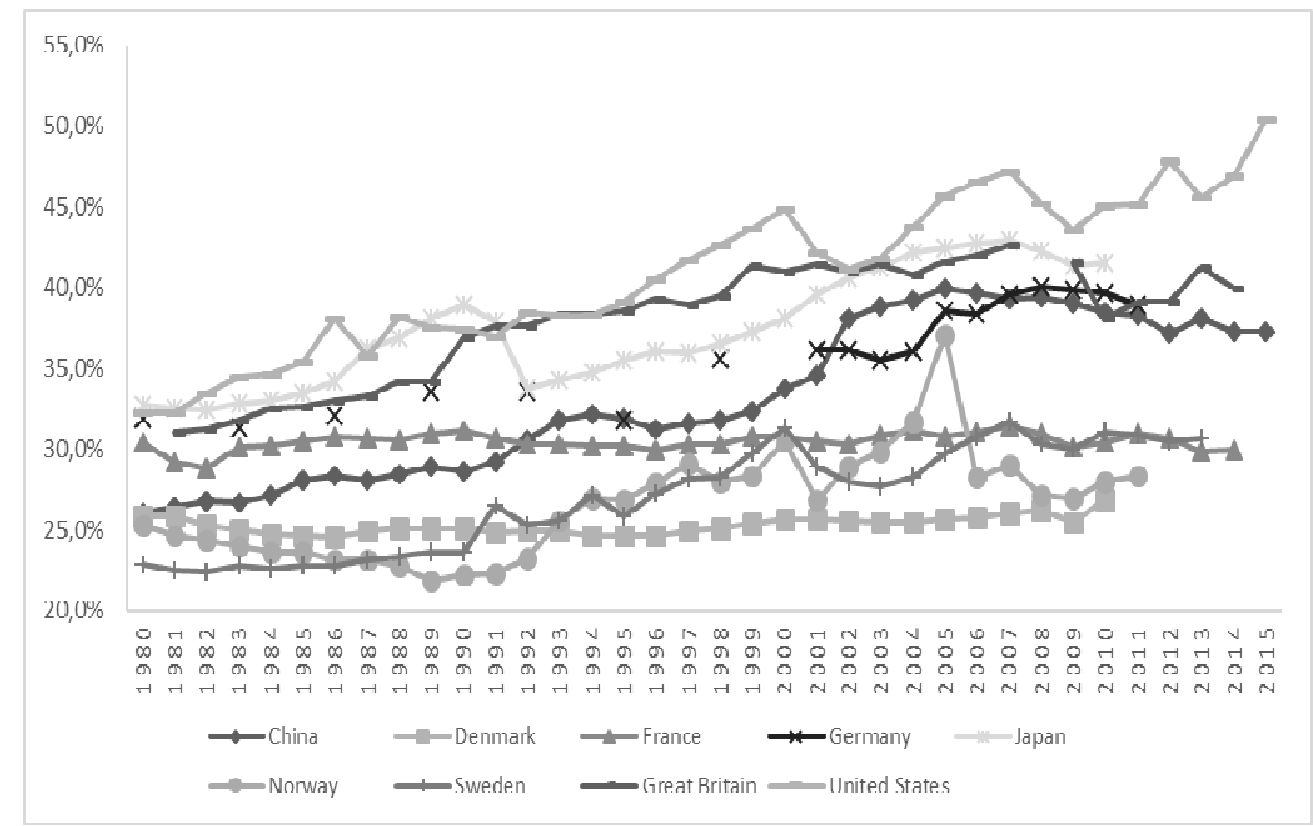

Source: World Wealth and Income Database

As can be seen from figure 2, the top decile's share in the national income has increased across all countries (except France). Growth differences are, however, significant. If in the case of Scandinavian countries (Sweden, Norway and Denmark) the share increases by several percentage points, in the Anglo-Saxon states and China, the growth is more pronounced (from 10 to 20 percentage points).

We have a better overview of growing income and wealth inequality if we look at the first $1 \%$ of the hierarchy (Figure 3). And in this case, the concentration of national income is visible in all the countries for which we

6 For methodology and project results see World Inequality Database (available online at http://wid.world/world/). 
have data available. For the Anglo-Saxon countries, we see almost a tripling of the share in national income detained by the first $1 \%$.

Figure 3. The share in national income of the top $1 \%$

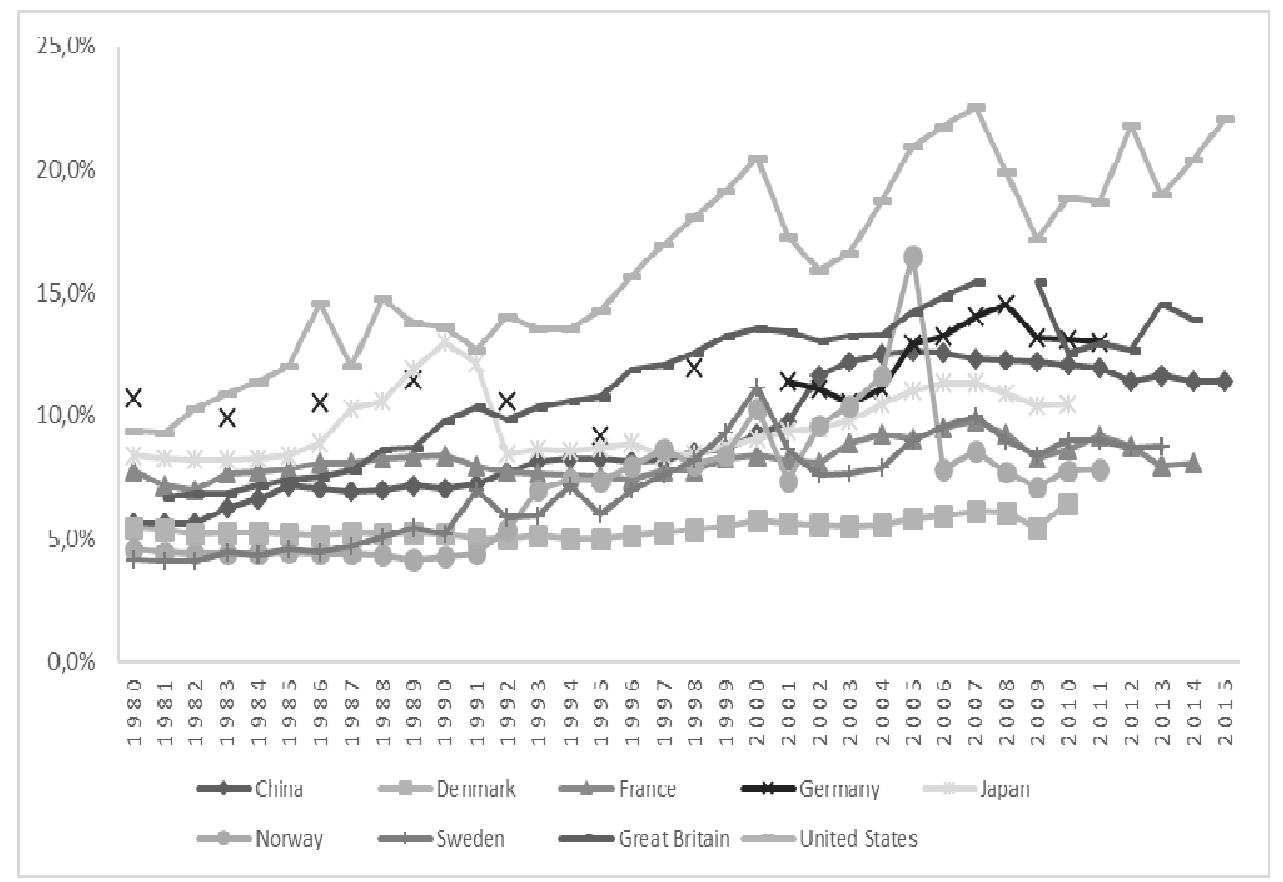

Source: World Wealth and Income Database

More importantly to be discussed is the ratio between the share of income and wealth owned by the top decile and the first $1 \%$ from this decile. If we compare the two sets of data, we notice that, for example, in the case of the United States of America, the top 10\% of the income distribution accounts for half of the national income, but almost half $(22 \%)$ is owned by the first $1 \%$. In the case of Great Britain, the share of the top decile in national income is $40 \%$, but $14 \%$ is owned by the first $1 \%$. In China, the share of the top decile in national income is $37 \%$, but almost one third is owned by the first $1 \%(11.4 \%)$. Therefore, as a first remark, it is important to note that after 1980, the share of the top decile's income in national income has increased in all high-income countries studied by Piketty. Also, the main 
beneficiaries of this growth are the first $1 \%$ of the hierarchy or super managers, as Piketty calls them, consisting of both financial and non-financial managers. A second remark concerns the use of indicators of inequality in official reports of national governments or international organizations. An indicator of inequality often used is the interdecile ratio P90/10 that is, the ratio between the ninetieth percentile of the income distribution and the tenth percentile. However, this indicator omits to consider the income distribution beyond the ninetieth percentile. Thus, the inter-governmental reports and statistics ignore the top of the distribution and provide no information on incomes inside the top decile (Piketty 2015, 442), as the first $1 \%$ can hold between one-third and a half of the income in the last decile, as shown above.

A popular theory for explaining income inequality growth in highincome countries is the marginal productivity theory and the relationship between technological change and education. According to this very popular theory among Anglo-Saxon economists, wage growth reflects 'technical advances in favour of high qualifications, which has made the productivity of the most skilled employees grow much faster than average productivity (Piketty 2015, 518). This means that technological changes have imposed a certain level of higher qualifications which has in turn led to an increase in employee productivity, compared to those in other sectors of the economy less intensive in skills. But as Piketty shows in his study, income inequality growth in the Anglo-Saxon countries is much more pronounced than that of Western European states or Japan, which are at the same level of technological development. As Piketty remarks $(2015,530)$ :

'The divergence between the various regions of the wealthy world is all the more striking because technological change has been the same more or less everywhere: in particular, the revolution in information technology has affected Japan, Germany, France, Sweden, and Denmark as much as the United States, Britain, and Canada. Similarly, economic growth - or, more precisely, growth in output per capita, which is to say, productivity growth - has been quite similar throughout the 
wealthy countries, with differences of a few tenths of a percentage point' (Piketty 2015, 530).

Thus, explaining income inequality between the high-income states, but above all the differences in income distribution within them, must also consider the political and ideological apparatus that most often justifies these income inequalities.

At the other side of the income distribution more people are at risk of poverty. The World Bank, one of the leading institution in assessing the number of people at risk of poverty, states that, at the global level, the number of people living on less than 1 dollar per day decreased from 1,5 billion in 1981 to 805 million at the end of 2000s (Deaton 2017, 256). But if we exclude China, whose outstanding economic growth in the last decades has helped decrease the number of people in poverty, the number of people living in poverty (less than 1 dollar per day in constant 2005 US\$) has slightly dropped from 785 million in 1981 to 708 million in 2008 (Deaton 2017, 256-257). The world's region where the fight against poverty has yet to show its effects is Sub-Saharan Africa. Even though the share of persons living with less than 1 dollar per day in constant 2005 US\$ has dropped from $43 \%$ in 1981 to $37 \%$ in 2008 , the region has higher fertility rates so the number of people in poverty actually increased from 169 to 303 million people (Deaton 2017, 257). Thus, despite the high pace growth that many developing countries experience, we are still living in a world where the poorest three-quarters of the world population share $20 \%$ of the world income, the same share as the top 1.7\% (Hoffer, Laliberté, and Gross 2013, 6).

Restraining our argument to EU, the number of people at risk of poverty ${ }^{7}$ has increased from 80 million in 2008 (before the recent economic crisis) to almost 87 million in $2016^{8}$, undermining the Europe 2020 Strategy to reduce the number of people at risk of poverty by 20 million. After 2008, the most widespread government response to the global financial crisis has

\footnotetext{
7 The number of persons with an equivalised disposable income below the risk-of-poverty threshold, which is set at $60 \%$ of the national median equivalised disposable income (after social transfers).

8 Eurostat (http://ec.europa.eu/eurostat/tgm/table.do?tab=table\&init $=1 \&$ language $=$ en\&pcode $=\mathrm{t} 2020$ _52\&plugin $=1$ ).
} 
been a series of cutbacks in public spending, mainly social spending and funding for social services, resulting in an accentuated growth of socioeconomic inequalities, social insecurity and precariousness, especially toward the bottom of the income structure (Sassen 2014).

\section{Kuznets's theory meets Central and Eastern Europe}

One of the well-known theories to explain income inequality belongs to the economist Simon Kuznets. In his article from the mid-1950s, Kuznets will launch his famous theory, later called the Kuznets curve. According to the American economist, during the industrial and economic modernization (characterized by the transition from agriculture to industry), income inequality follows a bell-like curve, increasing naturally at the beginning until it stabilizes to a certain extent, so that once the economy develops (in the sense of modernization), the gaps are to be reduced (Kuznets 1955). Kuznets's understanding of growing and decreasing income inequality is rather simplified. For Kuznets, income inequalities are the result of changes in economic structures, by passing from an agricultural to an industrial economy. Once the share of the population that worked in agriculture was diminished and will migrate to cities to work in industry, the income gap between farmers and industry workers will be reduced, and the differences will remain only among the employees among the urban population. The latter will be reduced through labour unionization and wage increase. Economic modernization will bring with it a demographic transition and changes in family patterns (Kuznets 1955). Thus, income inequality (and its decrease) is the result of structural changes in various economic sectors as economic modernization takes place, and is not the result of specific public policies.

Can Kuznets curve be applied in explaining income inequality in postsocialist states? Firstly, the initial conditions of application do not correspond, the former socialist states having a level of industrialization close to those of Western Europe, and the demographic transition already 
took place. In addition, the former socialist countries have already gone through a phase of national industrialization (represented by socialist policies), through which income inequalities have declined compared to the interwar period. Yet, after the first decade of transition, the average Gini coefficient for the former socialist states grew from 22 in 1989 to 34 in 2001, while in the United States (a traditionally unequal country), the growth was only by three percentage points in these interval (Bandelj and Mahutga 2010b, 2134).

To explain the differences between former socialist countries in terms of pace of income inequality growth, Bandelj and Mahutga (2010a, 2010b) argued that there are four major processes which created these differentiations: a) the level of privatization; $b$ ) the degree of state support in assuring safety nets; c) the existence of a large ethnic minority and d) the level of foreign investments. According to the two researchers, income inequality is higher in countries where: the share of the private sector is higher9; social public spending is lower; there is at least one ethnic minority with significant share; the foreign direct capital dominates the domestic one. Bandelj and Mahutga will insist on the latter process to argue how foreign direct investment (FDIs) has helped increase income inequality. First of all, FDIs have penetrated Eastern Europe in sectors such as business, foreign trade and financial services, sectors that require a more skilled workforce and which, due to the technology used, also have higher labour productivity. Second, there are income differences between managers of foreign-owned companies and their employees (Bandelj and Mahutga 2010b). In conclusion, FDIs can increase income disparities between the economic sectors financed by them and the domestic ones, due to the high productivity and the absorption of skilled workers compared to the semiskilled or unskilled ones which are heading towards the domestic sectors of the economy.

\footnotetext{
9 The relationship between the level of privatization, the share of foreign investments in financial services and external trade, the degree of urbanization and the share of the rural population as important factors in the growth of postsocialist inequalities was tested also in other studies (see Franco and Gerussi 2013; Rose and Viju 2014)
} 
If we return to the applicability of Kuznets's curve and consider the studies discussed above, we can conclude that we are witnessing a new trend of growing income inequality that transcends the rural economyindustry dichotomy. The domains 'responsible' for growing income inequality are those that provide advanced technologies and services such as communications, insurance and finance - supported by foreign investment and the main beneficiaries are the employees working in these advanced sectors (as we can also see in Romania's case below).

\section{A global overview of income inequality in Romania}

This present study is complementary to a rather burgeoning literature on income inequality and poverty in Romania after 1989. I do not intend to make a review of the large literature that discusses income inequality in Romania, but my intention is rather to highlight some typologies of studies that debate the process discussed. While some studies are more descriptive in their endeavour to highlight the changing structures of inequalities based on rural-urban divisions, labour market participation and educational attainment (e.g. Precupețu 2013), or use inequality and poverty indicators to compare EU's effort in reducing the at risk of poverty rate (Târa 2013), other studies use more sophisticated analytical and statistical tools in explaining income inequality. Franco and Gerussi (2013) show the effects of lax trade regulations and FDIs on income inequality. Investments from FDIs can upgrade the technological processes for export production in transition countries, and therefore creates a gap between unskilled and skilled workers. The same type of arguments are used by Bandelj and Mahutga (2010a, 2010b) as I have shown in the previous section. Rose and Viju (2014) take into consideration in their analysis economic (GDP per capita, inflation and FDIs), demographic (the share of rural population, the degree of urbanization, the share of individuals that attained primary education) and political (the degree of privatization, the role of government in reducing inequality, political rights) indicators to explain income inequality and 
conclude that the main factors that contribute to income inequality are the share of the private sector in the economy and inflation (measured as the growth rate of the GDP deflator). Finally, Garnero et al. (2015) analyse how collective bargaining coverage and the mechanism of minimum wage setting affect wage inequality and conclude that Romania, Greece and Portugal offer stronger protection than the majority EU countries with statutory minimum wage due to their relative high bargaining coverage.

My purpose for this article is more modest. I intend to show a global overview of income inequality after 1989 and to pinpoint some macrostructural processes that led to the current situation.

The synthetic measure to reveal income inequality is the Gini coefficient. Gini can take a value between 0 (perfect equality) and 100 if the last percentile would hold all the income. The advantage of the Gini coefficient is that it does not depend on either a unit of measure or the size of a country/population. Thus, comparisons can be made between countries with very different socio-demographic characteristics. Romania has undergone grosso modo through two waves of growing income inequality since 1989. After the first wave of economic restructuring in the 1990s, the Gini coefficient remained constant in the early 2000s, around 30, but rose sharply after 2004, with the introduction of the flat income tax of $16 \%$, causing a second wave of economic inequalities after the one in 1990s.

Looking at the performance of other CEE countries to reduce economic inequality, we can see that, for example, the Czech Republic and Slovenia have managed to maintain their Gini coefficient close to its 1989 value but also to the values of the Scandinavian states, suggesting that postsocialism does not necessarily lead to growing income inequality.

Like any simplified measure, the Gini coefficient also has its drawbacks. It is quite difficult to sum up a multidimensional reality through a one-dimensional indicator. The Gini coefficient measures both labour and capital incomes, which, as Piketty argues (2015), have rather different economic mechanisms and instruments for normative justification. 
Figure 4. Gini coefficient for seven former socialist states and EU (1989-2016)

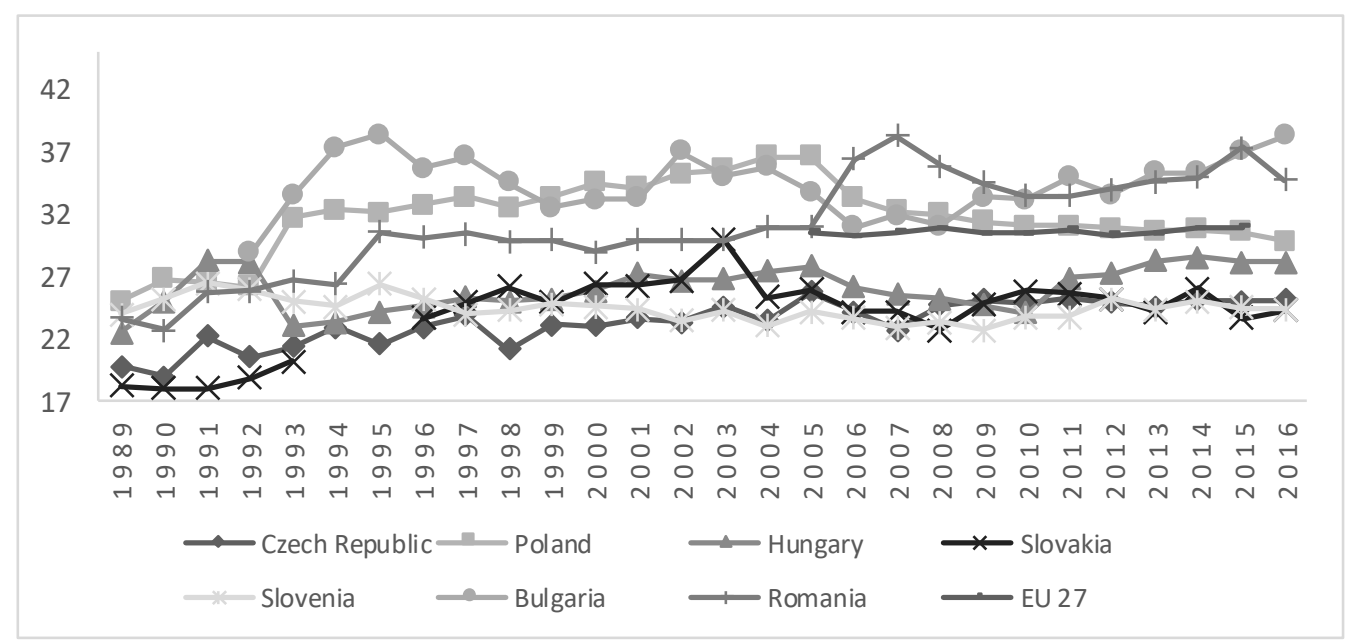

Source: TransMonEE and Eurostat [ilc_di12]

Therefore, it would be preferable to look at the different share of deciles, centiles and quintiles in the national income, as measures more appropriate to the distribution of income. Thus, we have an even grimmer picture if we look at the distribution of income by quintiles. Over $40 \%$ of national income is held by the upper quintile (Figure 5). Data from the World Institute for Development Economics Research show that if in 1990, the first quintile held $10.5 \%$ of the median disposable income, in 2015 the share dropped by half (5.1\%). In contrast, for the top quintile, the percentage grew from $33.6 \%$ to $42.5 \%$ of the median disposable income.

The ratio between the top and the bottom quintile (S80 / S20) in 2015 was 8.3, the highest value in the EU. Close to this value was Lithuania (7.3) and Bulgaria with a ratio of 7.1. Other countries in CEE were doing better, with Hungary having a ratio of 4.3, while in Poland the ratio was 4.9, far from the performance of countries like the Czech Republic (3.5) and Slovenia (3.6). After one decade (2004-2014), 20\% of Romanians held the same share of national income as their counterparts in Spain, Italy or Portugal, countries well known for their income inequality. 
Figure 5. Median equivalised disposable income by quintile group (\%)

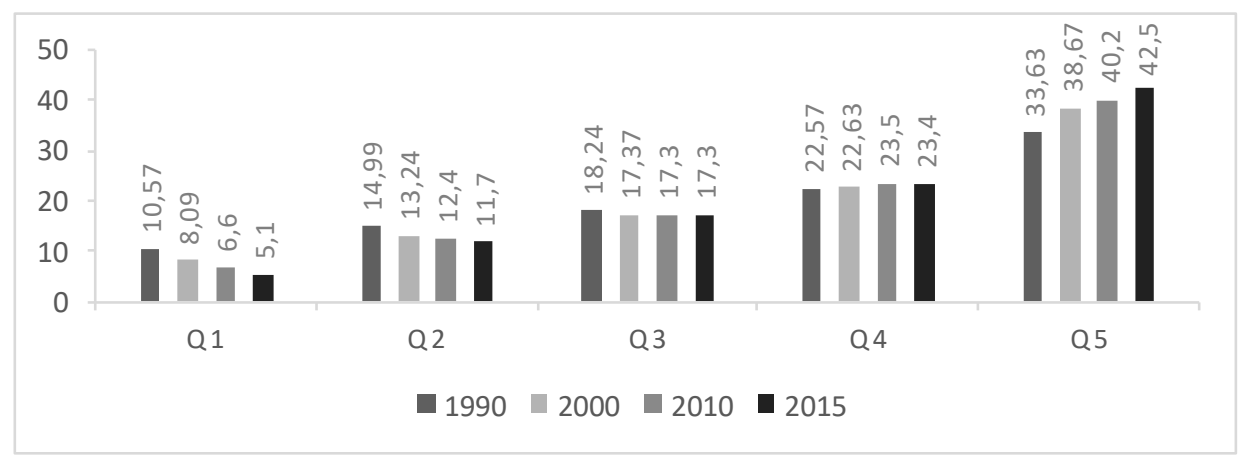

Source: World Income Inequality Database (WIID)

As argued in the above section on data sources in measuring income inequality, the growing income inequality is primarily reflected by the differences between wages and incomes derived from work in subsistence agriculture (including unpaid family workers) and informal economy. A recent NIS report showed that, in 2015, the share of in-kind income represented only $12.1 \%$ of the total household disposable income, a drop by 3.8 percentage points from the previous year, mainly due to a decrease in the value of income from own-consumption $(10.7 \%$, a drop by 3.5 percentage points from the previous year) (Institutul Național de Statistică 2015, 29-30). The same NIS report notes that the income gap between the top and the bottom decile is driven by the different share of wages in the households income, thus the wage based incomes are 44 times higher in the top decile than in the bottom decile (4310 RON per month per household in D10, compared to 98.7 RON per month in D1) ' $(2015,38-39)$.

Although being an employee considerably decreases the risk of being in poverty, the wage policy during transition has focused on maintaining a low minimum wage so that Romania remains attractive to foreign investors. As the figure below from Eurostat shows, the minimum wage in Romania, expressed in Euro ${ }^{10}$, is among the lowest in the EU, being only surpassed by

\footnotetext{
${ }^{10}$ Meanwhile, the minimum wage in Romania rose to 1,900 RON (413 euros). For comparative reasons, I have kept the 2015 values reported by Eurostat
} 
Bulgaria (Figure 7). Corollary, even in times of economic crisis, the state has virtually left the profits untaxed and moved the burden on the shoulders of employees and consumers. The share of GDP in the different types of taxes clearly indicates the huge difference between the two types of budgetary sources.

Figure 6. The S80/S20 ratio in 2015

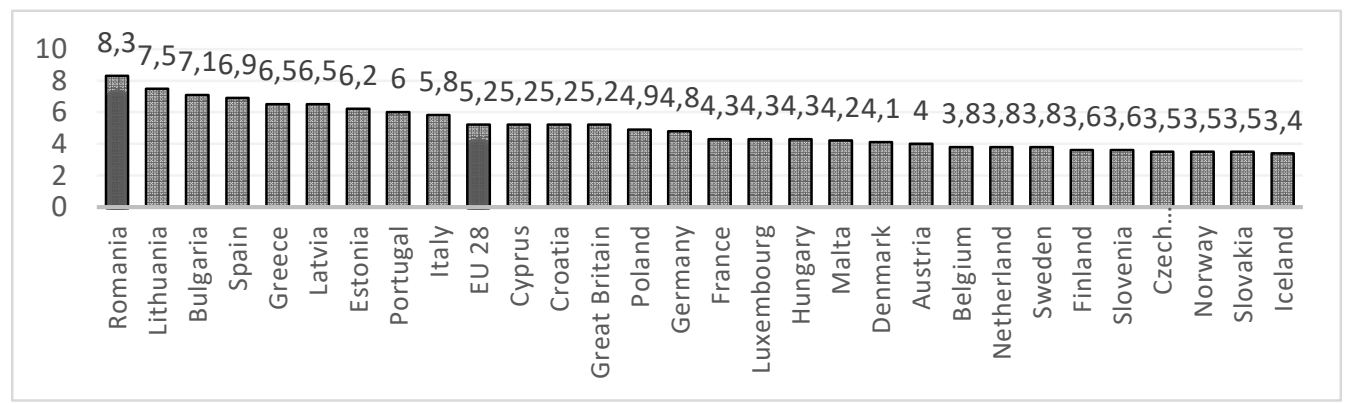

Source: Eurostat [ilc_di11]

Figure 7. Minimum wage in the EU (in Euro), 2015

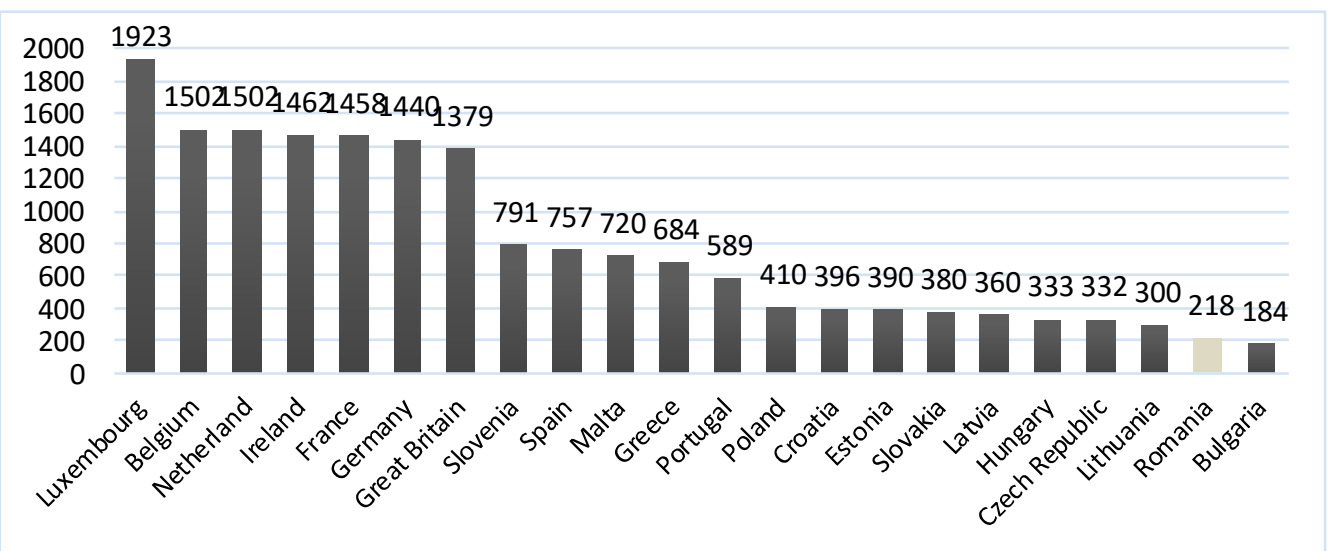

Source: Eurostat [tps00155]

If more than half of Romania's employees earn between roughly 220 and 440 gross Euro, less than 10 per cent of employees have a gross salary of over 1,000 Euro (Figure 8). The flexibilization of the labour code in favour of 
the multinational capital and the weakening of trade unions power risk threatening employees with temporary or part-time contracts in a state of social precariousness and a massive decline in living standards. According to Eurostat, Romania has the largest share of people in part-time work at risk of poverty $(59 \%)$, three and a half times higher than the average of the 10 states that joined EU in the 2004 wave (17.3\%).

Figure 8. The relative distribution of employees by income groups in October 2015 $(\mathrm{RON})$

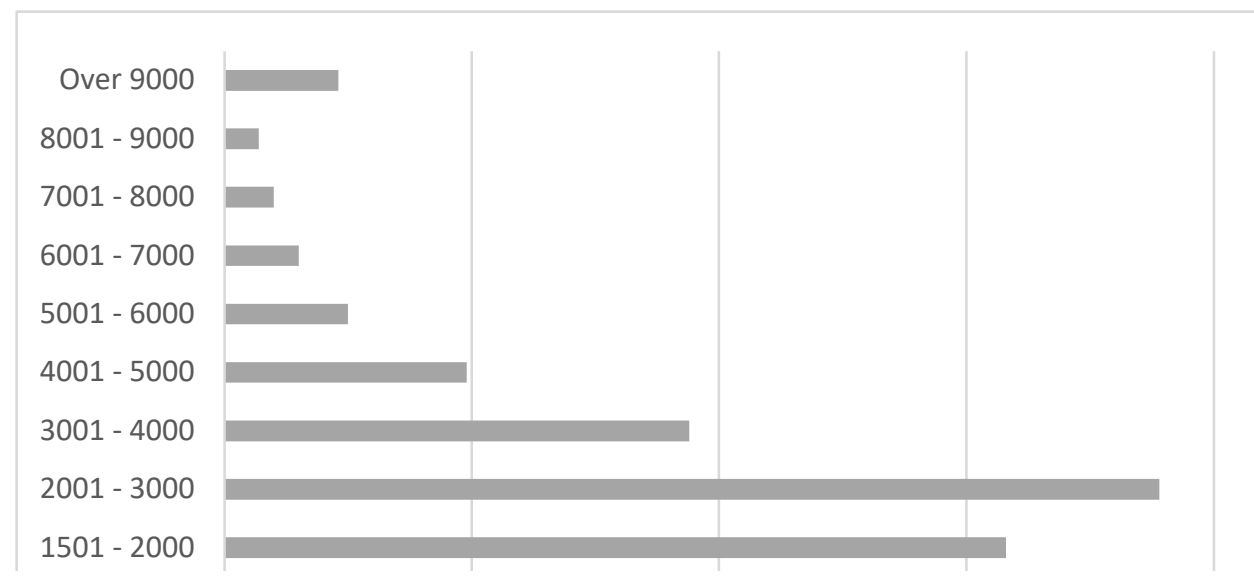

Source: Romania's Statistical Yearbook (2016)

At the same time, the at risk of poverty rate for employees with a contract of limited duration is $12.1 \%$ in Romania, below EU 28 (15.6\%) and EU10 (17.4\%) and two times lower than other CEE countries, such as Hungary (32\%) and Bulgaria (24.7\%). However, this indicator is less relevant for Romania, as the share of employees with a contract of limited duration is $1 \%$ in 2015. Because of Romania's atypical employment structure, with a third of its workforce in informal economy: day labourers, working in subsistence agriculture or unpaid family workers, the last two categories representing $90 \%$ of the workforce working in agriculture - the European statistics underrates the share of workers in temporary jobs, since employment without a legal form is by its nature, temporary (Domnișoru 2014, 25). 
Table 2. Share of wages by activity from the average net monthly wage (2008-2015)

\begin{tabular}{|l|l|l|l|l|l|l|l|l|}
\hline & 2008 & 2009 & 2010 & 2011 & 2012 & 2013 & 2014 & 2015 \\
\hline Monthly net nominal wage (RON) & 1309 & 1361 & 1391 & 1444 & 1507 & 1579 & 1697 & 1859 \\
\hline Agriculture, forestry and fishing & 0.70 & 0.74 & 0.74 & 0.72 & 0.73 & 0.75 & 0.75 & 0.74 \\
\hline Extractive industry & 1.75 & 1.73 & 1.75 & 1.78 & 1.85 & 1.86 & 1.92 & 1.86 \\
\hline Manufacturing industry & 0.80 & 0.84 & 0.89 & 0.92 & 0.92 & 0.93 & 0.93 & 0.92 \\
\hline $\begin{array}{l}\text { Electricity and heat energy, gas, } \\
\text { hot water }\end{array}$ & 1.83 & 1.89 & 1.92 & 1.93 & 1.93 & 1.85 & 1.82 & 1.66 \\
\hline $\begin{array}{l}\text { Water distribution, sanitation, } \\
\text { waste, decontamination }\end{array}$ & 0.88 & 0.91 & 0.90 & 0.92 & 0.92 & 0.90 & 0.89 & 0.85 \\
\hline Construction & 0.89 & 0.79 & 0.81 & 0.86 & 0.79 & 0.75 & 0.73 & 0.76 \\
\hline Trade & 0.80 & 0.77 & 0.84 & 0.85 & 0.87 & 0.82 & 0.83 & 0.85 \\
\hline Transport and storage & 1.11 & 1.12 & 1.12 & 1.09 & 1.08 & 1.03 & 1.01 & 1.00 \\
\hline Hotels and restaurants & 0.59 & 0.59 & 0.57 & 0.58 & 0.56 & 0.57 & 0.56 & 0.58 \\
\hline Information and communication & 1.62 & 1.81 & 1.93 & 2.05 & 1.99 & 1.94 & 1.98 & 2.06 \\
\hline Financial and insurance services & 2.45 & 2.28 & 2.30 & 2.38 & 2.38 & 2.31 & 2.19 & 2.15 \\
\hline Real estate & 0.97 & 0.88 & 0.85 & 0.88 & 0.83 & 0.85 & 0.79 & 0.82 \\
\hline $\begin{array}{l}\text { Professional, scientific and } \\
\text { technical activities }\end{array}$ & 1.34 & 1.37 & 1.38 & 1.43 & 1.47 & 1.49 & 1.44 & 1.48 \\
\hline $\begin{array}{l}\text { Administrative and support } \\
\text { service activities }\end{array}$ & 0.64 & 0.64 & 0.68 & 0.67 & 0.68 & 0.72 & 0.74 & 0.77 \\
\hline $\begin{array}{l}\text { Public administration and } \\
\text { defence, public social security } \\
\text { system }\end{array}$ & 1.84 & 1.59 & 1.41 & 1.32 & 1.39 & 1.53 & 1.62 & 1.56 \\
\hline Education & 1.17 & 1.17 & 0.99 & 0.91 & 0.91 & 0.97 & 1.02 & 1.01 \\
\hline Health and social work & 0.97 & 0.99 & 0.88 & 0.84 & 0.87 & 0.92 & 0.88 & 0.89 \\
\hline Cultural and recreational activities & 0.91 & 0.92 & 0.79 & 0.75 & 0.76 & 0.77 & 0.74 & 0.75 \\
\hline
\end{tabular}

Source: National Institute of Statistics (NIS), Tempo database [FOM106E]

If we take a glance at the differences between annual average net wages earned by employees in different economic sectors, we notice that the lowest wages are to be found in domains such as hotels and restaurants, agriculture and manufacturing, which are followed by construction and trade services. Then, higher incomes are to be found for employees working in real estate, health and social care, education and public administration. On the next level, at a significant distance from the previous group we find 
the mining and extraction industry, followed by the information and communication and financial and banking sectors, the latter being the sectors with the highest net incomes (2.15 times higher than the average net salary). Thus, the highest net salaries are found in both the sectors penetrated by FDI (information and communications and financial and insurance services) and in those in which the state holds monopoly or control of resources (extractive industry, public administration and defence).

\section{Discussion}

In order to understand the processes of growing income inequality in the last four decades, one has to consider the economic, social and political factors that shaped this process. I have shown in this article that the rising income inequality is the result of changes in post-1980 public policies embedded in the so-called neoliberal revolution or 'Washington consensus'. In most of high-income, Western states, the share of national income held by the top decile, and especially the first $1 \%$ of this decile, has grown considerably in just 30 years. The theory of marginal productivity and the relationship between technological change and education can only partially explain these increases. Although neoliberal policies (liberalization, privatization and deregulation) were presented by the international financial institutions (especially the World Bank and the International Monetary Fund) as blueprints for regaining economic growth and, in the late 1980s and the 1990, became the 'only game in town', in CEE (as also in Latin America) these policies were blended with structural adjustment programs and austerity policies that 'helped increase income inequality, because of the dramatic restructuring of these economies. As a consequence, during this period, all postsocialist countries experienced an increase in the Gini coefficient, as I have shown in Figure 4.

Moreover, the role of national governments in explaining income inequality needs to be also reconsidered. Former World Bank chief economist Joseph Stiglitz notes that inequality is also the result of government policies, both in what the government does and what it does 
not do` (Stiglitz 2013, 35). Governments can increase inequalities by masking upward redistribution. Often, these policies reflect government subsidies to economic actors (corporations), laws that make the market less competitive, lax competition, law enforcement, etc. Also, low taxation of dividend tax and capital gains have created a window for the top $1 \%$ of the income hierarchy to considerably increase their wealth, as capital and dividends inequities' are much higher than those based on wages (Stiglitz 2013, 96). Thus, the history of inequality is not only economic, but also a political one!

Turning to Romania, growing income inequality in postsocialism is the result of macro-structural changes in the Romanian economy, but also to political decisions taken during this period. First, Romania's status of a dependent economy has shaped its wage policy all these years. In order to remain attractive to foreign investors, Romania has proposed a minimum wage almost unbeatable throughout the region. More than half of Romania's employees earned less than average wage in 2015, while the share of those who earned more than 1000 euros was below 10\%. Following the waves of economic restructuring in the 1990s, the Gini coefficient remained constant in the early 2000s, around 30, but rose sharply after 2004, with the introduction of the flat income tax of $16 \%$, causing a second wave of income inequality after the 1990s.

The flat income tax was intended to help the households save money for further investment, but its effects were not necessarily the ones expected. The research conducted by Liviu Voinea and Flaviu Mihăescu at the end of 2000, based on the Household Budget Survey, showed that on average, with the introduction of the flat income tax, the gains per employee were $3.73 \%$ of his/her net wage and only $2 \%$ of the employees gained more than $10 \%$ of their wage. Moreover, $10 \%$ of the employees received $40 \%$ of the gains from the introduction of the flat income tax (Voinea and Mihăescu 2009, 29). At the same time, the corporate tax was cut from 25 to $16 \%$ and in addition, in Romania, there is no wealth tax, while property taxation is rather low (Stănescu and Dumitru 2017, 8). 
Looking at the efforts of other former socialist countries to reduce income inequality, we remarked that, for example, the Czech Republic and Slovenia have managed to maintain their Gini coefficient close to its 1989 value and also to the values of the Scandinavian countries, suggesting that postsocialism does not necessarily lead to growing income inequality. Corollary to the first conclusion, one more aspect that is worth mentioning is the 'shrinking` of the government's social agenda in the face of multinational capital. Romania became an economy dependent on FDIs over the 2000s. If the share of FDIs in GDP at the beginning of 2000 was $10 \%$, at the end of the decade, it reached $42 \%$ of GDP, being an important source for the modernization of enterprises in order to increase their exports and also to finance the country's current account deficit. Thus, in order to remain attractive to FDIs, the solutions proposed by the Romanian governments were aimed at controlling labour costs and subordinating labour to capital by: a) moving the tax burden from capital to labour and consumption; b) eroding the intermediary institutions between employer and employee that could press for wage increases (trade unions and social dialogue institutions), thus reducing capital costs and c) tightening access to unemployment and social services (see Ban 2014; Trif 2013).

\section{Conclusions}

Over the past decades, there has been a widespread concern for comparing income inequality at the European and world level. In this sense, more efforts to generate comparative databases have been undertaken by both intergovernmental and academic institutions. I have shown in this article the main methodological problems that the assessment of income inequality through comparative databases can pose. Still, there is no common ground on conceptualizing inequality indicators and measuring them, some of which are income-based, while others are household expenditure-based.

Analysing Romania's case, one can see that measuring income inequality by standard measures can pose serious methodological problems 
because of the high share of informal work, remittances from migration, the atypical occupational structure and the importance of own-consumption in reducing inequality, that makes Romania an exceptional case in the EU. Romania still has a large part of its workforce employed in subsistence agriculture (including unpaid family workers) and informal economy with low and fluctuating incomes. It also has the largest shares of incomes coming from own consumption, reflected in the household income structure (Figure 1).

Taking all this into consideration, it is not surprising that Romania became one of EU's most unequal countries. If we look at some classical inequality indicators, we can see that during transition to the market economy, the lower quintile's share of the median disposable income has dropped by half, while the upper quintile's share has grown with almost $10 \%$. Put it in other words, over $40 \%$ of national income is held by the upper quintile.

In my endeavour to explain rising income inequality, I critically interrogate Kuznets' famous theory regarding rising income inequality during time of structural changes, by arguing that his theory disregards the effects of specific public policies. As some scholars argued (e.g. Bohle and Greskovits 2012), almost all postsocialist countries open their economies towards foreign investments and implemented specific public policies that would make their economies more business friendly. Thus, by maintaining a low wage policy, correlated with the repression of the trade unions capacity of negotiation (since 2011), more than half of the employees earn a wage below the medium gross wage in Romania. The higher wages are to be found in the sectors penetrated by foreign direct investments or the ones where the state has the monopoly or control over the resources. In order to reduce income inequality, public policies should redirect their efforts in reducing the gap between individuals who earn their income from wages and those that work in subsistence agriculture, by stimulating more paid jobs in the latter. Also, progressive taxation should be introduced in sectors with higher wages, like financial and insurance services, information and 
communication or in industries where the state holds monopoly of control over resources like extractive industry or public administration and defence due to the fact that wages received are not the result of market mechanisms.

\section{References}

Ban, Cornel. 2014. Dependență și dezvoltare. Economia politică a capitalismului românesc. Cluj-Napoca: Tact.

Bandelj, Nina and Matthew Mahutga. 2010a. "Rising Income Inequalities in Central and Eastern Europe: The Influence of Economic Globalization and Other Social Forces." In Globalization and Transformations of Social Inequality, edited by Ulrike Schuerkens, 193218. New York: Routledge.

Bandelj, Nina and Matthew Mahutga. 2010b. "How Socio-Economic Change Shapes Income Inequality in Post-Socialist Europe." Social Forces 88(5): 2133-2161.

Bohle, Dorothee and Béla Greskovits. 2012. Capitalist Diversity on Europe's Periphery. Ithaca and London: Cornell University Press.

Deaton, Angus. 2017. Marea evadare. Sănătatea, bogăția și originile inegalității [The Great Escape: Health, Wealth, and the Origins of Inequality]. București: Litera.

Deininger, Klaus and Lyn Squire. 1996. "A New Data Set Measuring Income Inequality." The World Bank Economic Review 10(3): 565-591.

Domnișoru, Ciprian. 2014. The largest drop in income inequality in the European Union during the Great Recession: Romania's puzzling case. Geneva: International Labour Organisation.

Eurostat. n.d. People at risk of poverty after social transfers. Code t2020_52. Accessed 2017, July 11.

http://ec.europa.eu/eurostat/tgm/table.do?tab=table\&init=1\&lang uage $=$ en\&pcode $=$ t2020_52\&plugin $=1$

Eurostat. n.d. S80/S20 income quintile share ratio - EU-SILC survey [ilc_di11]. Accessed 2017, July 11.

Eurostat. n.d. Minimum wage in the EU [tps00155]. Accessed 2017, July 11.

Eurostat. n.d. Gini coefficient of equivalised disposable income - EU-SILC survey [ilc_di12]. Accessed 2017, July 11.

Franco, Chiara and Elisa Gerussi. 2013. "Trade, foreign direct investments (FDI) and income inequality: Empirical evidence from transition 
countries." The Journal of International Trade \& Economic Development 22(8): 1131-1160.

Galbraith, James. 2016. Despre inegalitate. Teoria inegalității economice pe ințelesul tuturor [Inequality: What Everyone Needs to Know]. București: Publica.

Garnero, Andrea, Stephan Kampelmann, and François Rycx. 2015. "Minimum wage systems and earnings inequalities: Does institutional diversity matter?" European Journal of Industrial Relations 21(2): 115-130.

Harvey, David. 2007. A Brief History of Neoliberalism. Oxford: Oxford University Press.

Hoffer, Frank, Pierre Laliberté, and Tandiwe Gross. 2013. The Challenge of Inequality: Time for Change. Geneva: International Labour Organization.

ICCV. 2010. Raportul social al ICCV. După 20 de ani: opțiuni pentru România. București: Institutul de Cercetare a Calităţii Vieții.

Institutul Național de Statistică (NIS). 2015. Coordonate ale nivelului de trai în România. Veniturile și consumul populației, în anul 2015. București: Institutul Național de Statistică.

Institutul Naţional de Statistică (NIS). n.d. Tempo database: Average monthly nominal net earnings by economic activities [FOM106E]. Accessed 2017, July 11.

Luxembourg Income Study Database (LIS). n.d. Cross-national Data Centre in Luxembourg. Accessed 2017, July 11.

http://www. lisdatacenter.org/our-data/lis-database/

Kuznets, Simon. 1955. "Economic Growth and Income Inequality." The American Economic Review 45(1): 1-28.

Paats, Merle and Ene-Margit Tiit. 2010. "Income from own-consumption." In Income and living conditions in Europe, edited by Anthony Atkinson and Eric Marlier, 179-194. Brussels: European Commission.

Piketty, Thomas. 2015. Capitalul in secolul XXI [Capital in the Twenty-First Century]. București: Litera.

Precupețu, Iuliana. 2013. "Inequality Trends in Romania." Calitatea Vieții XXIV(3): 249-276.

Rose, Sara and Crina Viju. 2014. "Income inequality in post-communist Central and Eastern European countries." Eastern Journal of European Studies 5(1): 5-19.

Sassen, Saskia. 2014. Expulsions: Brutality and Complexity in the Global Economy. Cambridge and London: The Belknap Press of Harvard University Press. 
Stănescu, Iulian and Mihai Dumitru. 2017. "Poverty and social exclusion in Romania: a consensual approach to material deprivation." Calitatea Vieții XXVIII(1): 3-25.

Stiglitz, Joseph. 2013. The Price of Inequality: How Today's Divided Society Endangers Our Future. New York and London: W. W. Norton \& Company.

Trif, Aurora. 2013. "Romania: collective bargaining institutions under attack." Transfer 19(2): 227-237.

Țâra, Sergiu. 2013. "Social inequalities and poverty in current Romania." Theoretical and Applied Economics 20(2): 129-144.

Voinea, Liviu, and Flaviu Mihăescu. 2009. "The Impact of the Flax Tax Reform on Inequality. The Case of Romania." Romanian Journal of Economic Forecasting 4: 19-41.

World Income Inequality Database (WIID) 3.4. n.d. United Nations University, Helsinki. Accessed 2017, July 11.

https://www.wider.unu.edu/project/wiid-world-incomeinequality-database

World Inequality Database (WID). n.d. Accessed 2017, July 11. http://wid.world/world/ 